\title{
Accidental introduction of alien plankton into the Sri Lankan coastal zone through ballast water of cargo ships
}

\author{
W. U. CHANDRASEKERA* and M. A. S. T. FERNANDO \\ Department of Zoology, University of Kelaniya, Kelaniya, Sri Lanka. \\ *Corresponding author (E-mail: upali@kln.ac.lk)
}

\begin{abstract}
Accidental introduction of alien plankton through ballast water is a major ecological issue in many countries in the world. As there are no local studies addressing this problem, the present study was carried out to see whether alien plankton are introduced into Sri Lankan coastal zone through ballast water. Marine plankton occurring within ballast water holds of five cargo ships arrived at Colombo harbour and three local sites including Colombo inner harbour and two neighboring coastal sites were sampled. The physico-chemical parameters of water samples were also measured. Data on species abundance and physico-chemical parameters were analyzed using multivariate and univariate statistical tests as appropriate.

Altogether 159 taxa of plankton were found in the samples. In the ballast water samples alone, there were 56 different taxa of which $50 \%$ of them were totally alien to the local coastal zone. The physico-chemical parameters of water samples between the four sites were not significantly different. However, multivariate statistical tests confirmed that the plankton community of the ballast water samples was significantly different from that of the three local sites. Considering the large number of ships calling annually at Colombo harbour, the great potential of accidental introduction of alien plankton into the Sri Lankan coastal zone should never be underestimated.
\end{abstract}

\section{Introduction}

Invasion of alien organisms through ballast water is one of the four greatest threats to the world's oceans as it has been estimated that approximately 70,000 cargo vessels of the world are transporting about 10 billion tons of ballast water globally per year indicating a global concern for this problem (Stewart 1991). It has been estimated that at any one time in excess of 3,000 species are in motion in the ballast water tanks of ocean going ships around the world (Carlton and Geller 1995) and a total of several thousands or even millions of organisms are transported in the ballast water holds of a single ship (Locke et al. 1993). 
Mass occurrence of the Asian phytoplanktonic algae Odontella (Bidulpphia) sinensis in the North Sea in 1903, reported by Ostenfeld (1908), was the first scientific evidence of species introduction via ballast water. During the second half of the last century, many studies on the introduction of various marine organisms through ballast water have been carried out (eg. Medcof 1975; Carlton 1985 and 1987; Vinogradov et al. 1989; Shushkina and Musayeva 1990; Hallegraeff and Bolch 1991; Reeve 1993; Subba Rao et al. 1994). Much of these alien palnkton cause ecological imbalances and lead into severe economic losses to their receiving countries through their invasiveness. For example the zebra mussel, an invasive mollusc species accidentally introduced via ballast water as a plankton, caused billions of dollars of damage by fouling underwater pipes in the Great Lakes in the USA (Roberts 1990; Lodge 1993; Gollasch 1997).

Since Sri Lanka is located in the middle of the trans-oceanic route connecting east and west, and Colombo harbour being a world famous commercial sea port, there is a huge potential of alien plankton being introduced into the Sri Lankan coastal zone via ballast water of the ships calling there. About 5000 ships arrive at this harbour annually and it has been estimated that about 1 million ton of ballast water is released by them into the costal waters in and around the harbour (Colombo Harbour master's statistics and personal communication). However, there are no local records available addressing this issue so that the present investigation was carried out to see whether alien plankton are introduced into the Sri Lankan coastal waters via ballast water of cargo ships.

\section{Materials and Methods}

Three local sampling sites, namely the Colombo Inner Harbour, Panadura and Pamunugama in the west coast of Sri Lanka were chosen for the study (Figure 1). Colombo Inner Harbour (Latitude $6^{\circ} 56^{\prime} \mathrm{N}$; longitude $79^{\circ} 51^{\prime} \mathrm{E}$ ) was selected as the first sampling site since it is location where the ballast water is discharged upon loading the ships. As the oceanic currents are generally northbound in the west coast (Jayaweera 1999), it was hypothesized that these alien plankton would drift with the ocean currents and there after found in northern locations so that the second sampling site was selected in the Pamunugama coast (Latitude $7^{\circ} 05^{\prime} \mathrm{N}$; Longitude $79^{\circ} 49^{\prime} \mathrm{E}$ ) which is situated about $30 \mathrm{~km}$ north to the Colombo harbour. If this is the case, only the local plankton would present in the sea south to the Colombo harbour so that the third site was selected from around the Panadura coast (Latitude $6^{\circ}$ $45^{\prime} \mathrm{N}$; longitude $79^{\circ} 52^{\prime} \mathrm{E}$ ) which is situated about $30 \mathrm{~km}$ south to the Colombo harbour. 


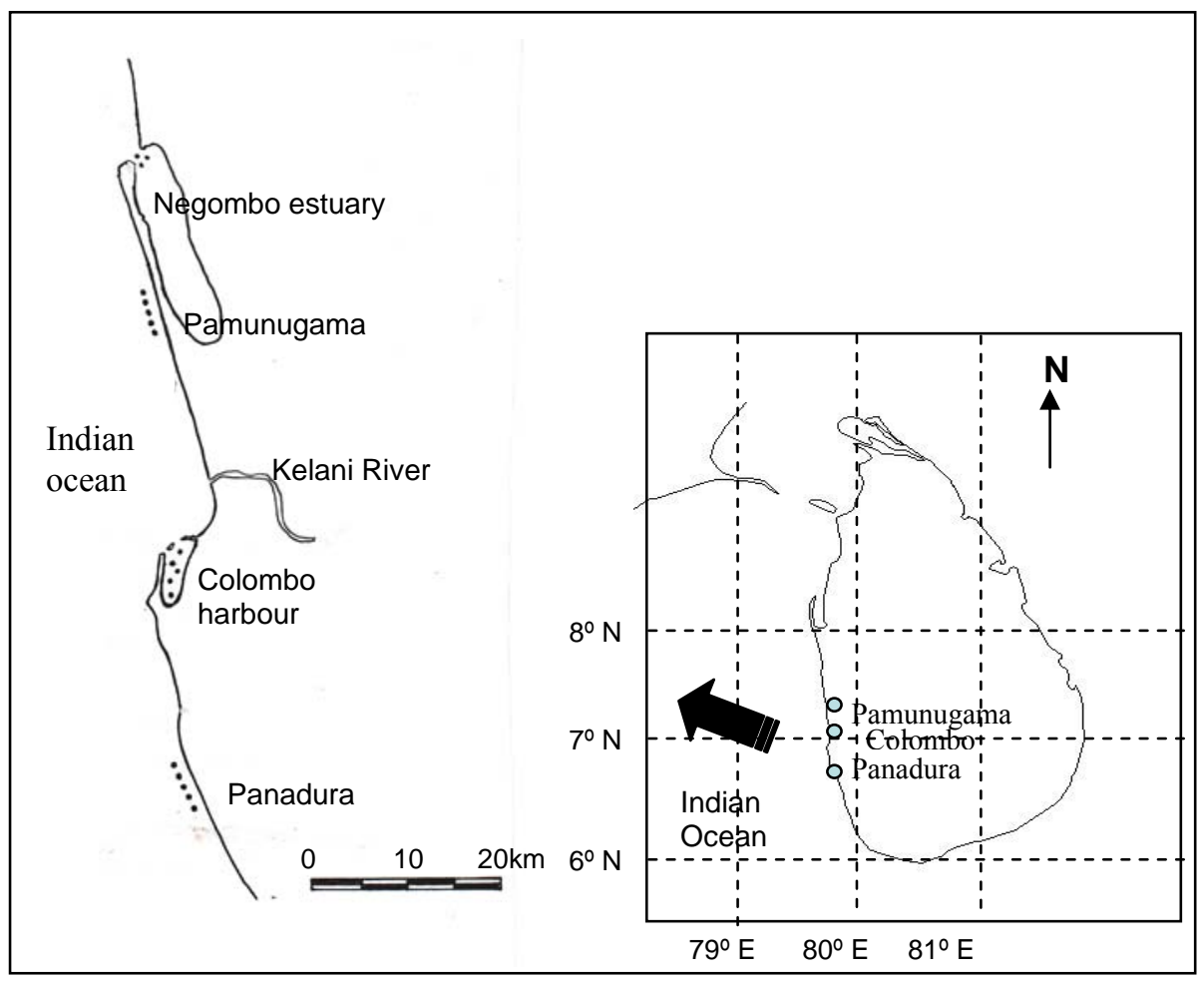

Figure 1. Map of the west coast of Sri Lanka showing the five sub-sampling locations $(\bullet)$ in the 3 local sampling sites; Colombo inner harbour, Panadura and Pamunugama. Inset shows the location of these local sampling sites ( $O$ ) in Sri Lanka.

Altogether five transverse plankton samples were collected from five random locations within the Colombo inner harbour by boat dragging a 55 $\mu \mathrm{m}$ plankton net along the water surface for a distance of about $5 \mathrm{~m}$ (approximate volume of water $=1 \mathrm{~m}^{3}$ ) in 28 July 2006. These plankton samples were emptied into labeled jars separately and preserved in situ using a $5 \%$ formalin solution and fixed by adding one drop of Lugols solution to 20 $\mathrm{ml}$ of the plankton extract. Five plankton samples were also collected and treated in the same manner from five locations in the Pamunugama coast in $20^{\text {th }}$ November 2006 and Panadura coast in $23^{\text {rd }}$ November 2006 each between 8.30 am and $2.00 \mathrm{pm}$ each. These five sampling locations at each site were about $250 \mathrm{~m}$ apart from each other and about $1.5 \mathrm{~km}$ to $2.0 \mathrm{~km}$ in the sea from the shore. Five other plankton samples were also collected from ballast water holds of five cargo ships called at the Colombo harbour (Table 1). However, the sampling procedure stated above had to be altered due to logistic reasons where approximately $1 \mathrm{~m}^{3}$ of ballast water was pumped out from the ballast tank from each ship and the plankton were collected by holding the plankton net across the ballast drain. These plankton samples were also preserved and fixed in situ using the method mentioned above. 
Table 1. The five cargo ships from which ballast water samples were collected in the present study

\begin{tabular}{lll}
\hline Name of cargo ship & $\begin{array}{l}\text { Last sea port called and } \\
\text { the country of departure }\end{array}$ & Sampling date \\
\hline 1. YM DUBAI & Port Klang, Malaysia & 10 November 2006 \\
2. X-PRESS RESOLVE & $\begin{array}{l}\text { Port Chittagong, } \\
\text { Bangladesh }\end{array}$ & 11 November 2006 \\
3. FLORIA-PANAMA & Port Penang, Malaysia & 11 November 2006 \\
4. HANJIN & Port Bombay, India & 15 November 2006 \\
5. IRENES RESPECT & Port Somalia, Somalia & 15 November 2006 \\
\hline
\end{tabular}

Since the growth and survival of plankton depend upon physicochemical parameters of water such as salinity, dissolved oxygen content, $\mathrm{pH}$, conductivity and temperature (Ricklefs 1990), those parameters between the four sites were measured in triplicate in situ using the salinity refractor meter (Model; ATAGO S-28), digital dissolved oxygen meter (Model; WTW-OXI315 i), digital pH meter (Model; WTW-pH 315 i), digital conductivity meter (Model; HATCH) and glass-mercury thermometer respectively. The plankton samples were brought to the laboratory and, were identified to the nearest possible taxonomic category using standard plankton identification keys provided by Wickstead (1965), Newell and Newell (1973), Arvin (1977), Boney (1979), Suwanrumpha (1987), Guglielmo and Ianora (1995) and Benson (2002). Plankton was enumerated under a binocular microscope using a Sedgwick rafter cell.

The percentage occurrence of the site-specific plankton in the four sampling sites were calculated and significant difference between them were tested using the Chi-Square test at $\alpha=0.05$. Significant difference between the clustered planktom sample, i.e. ballast water plankton samples and local samples in the Bray-Curtis similarity matrix (Clarke and Warwick 2001), was tested using one-way ANOSIM at $\alpha=0.05$ in the PRIMER (Version 5.2.9) statistical software package. Before the multivariate analysis the plankton abundance data were $\log _{10}(\mathrm{X}+1)$ transformed to reduce non-normality. The physico-chemical data were analyzed using one-way ANOVA at $\alpha=0.05$.

\section{Results}

Altogether 159 taxa of plankton were found in the 20 plankton samples collected from the four sampling sites. The percentage occurrence of these taxa at each sampling site is given in Table 2. Copepods, diatoms and dinoflagellates dominated in all samples. In addition, chlorophyceae algae, ciliates, cladocerans, rotifers, tintinids and larval forms of some fishes and invertebrates were also found but in lesser numbers. 
Table 2. List of plankton found in the water samples collected from the inner harbour, ballast tanks, Pamunugama and Panadura. The percentage occurrence of each taxa at each site $(n=5)$ is presented.

\begin{tabular}{|c|c|c|c|c|}
\hline \multirow[b]{2}{*}{ Taxon } & \multicolumn{4}{|c|}{ Percentage occurrence } \\
\hline & $\begin{array}{c}\text { Inner } \\
\text { Harbour }\end{array}$ & $\begin{array}{c}\text { Ballast } \\
\text { water }\end{array}$ & Pamunugama & Panadura \\
\hline \multicolumn{5}{|l|}{ Copepods } \\
\hline Acartia clause & - & - & - & 0.20 \\
\hline Acartia erythraea & - & 0.22 & - & - \\
\hline Acartiella sinensis & - & - & 0.54 & 0.78 \\
\hline Acrocalanus gibber & - & 0.66 & - & 0.98 \\
\hline Acrocalanus gracilis & 0.11 & 2.20 & - & - \\
\hline Acrocalanus longicornis & - & - & 0.11 & 0.10 \\
\hline Calanopia aurivilli & - & 2.20 & - & - \\
\hline Calanopia elliptica & - & - & - & 0.59 \\
\hline Calanopia thompsoni & - & 0.62 & - & - \\
\hline Calocalanus pavo & - & 2.20 & - & - \\
\hline Candacia bradyi & - & 0.88 & - & - \\
\hline Candacia curta & - & 1.98 & - & - \\
\hline Candacia discaudata & - & 4.40 & - & - \\
\hline Candacia sp. & 0.11 & - & - & - \\
\hline Canthocalanus pauper & 0.11 & - & - & - \\
\hline Centropages bradyi & - & - & 0.75 & - \\
\hline Centropages furcatus & - & 1.21 & - & - \\
\hline Centropages orsinii & - & 2.20 & - & - \\
\hline Clausocalanus arcuicornis & 0.11 & - & - & - \\
\hline Clausocalanus furcatus & - & - & 0.11 & - \\
\hline Eucalanus monachus & 0.34 & 0.45 & 0.54 & 0.49 \\
\hline Eucalanus pileatus & - & 2.20 & - & - \\
\hline Eucalanus subcrassus & - & 0.40 & - & - \\
\hline Euchaeta concinna & 0.22 & - & - & - \\
\hline Euchaeta marina & - & 0.22 & 0.11 & - \\
\hline Euterpina acutifrons & - & - & - & 0.69 \\
\hline Labidocera kroveri & - & - & - & 0.29 \\
\hline Macrosetella gracilis & - & - & - & 0.20 \\
\hline Oithona brevicornis & 0.35 & - & - & 0.20 \\
\hline Oithona nana & 0.34 & - & - & 0.69 \\
\hline Oithona plumifera & - & - & - & 0.31 \\
\hline Oithona rigida & - & - & - & 0.20 \\
\hline Oithona simplex & 0.45 & 2.42 & - & - \\
\hline Oncaea media & 0.11 & - & - & - \\
\hline
\end{tabular}

Table 2 continued on pages 92-95. 
Table 2. Continued from page 91.

\begin{tabular}{|c|c|c|c|c|}
\hline Taxon & $\begin{array}{c}\text { Inner } \\
\text { Harbour }\end{array}$ & $\begin{array}{c}\text { Ballast } \\
\text { water }\end{array}$ & Pamunugama & Panadura \\
\hline Paracalanus aculeatus & - & 2.20 & - & - \\
\hline Paracalanus parvus & - & - & - & 0.69 \\
\hline Parvocalanus crassirostris & - & - & 0.86 & 0.69 \\
\hline Pontellopsis yamadae & 0.11 & 0.44 & - & 0.39 \\
\hline Pseudodiaptomus aurivilli & - & 1.32 & - & 0.39 \\
\hline Pseudodiaptomus clevi & - & 0.22 & - & - \\
\hline Temora sp. & - & 0.22 & - & - \\
\hline Temora stylifera & - & - & - & 0.10 \\
\hline Cosmacalanus darwini & - & 2.20 & - & - \\
\hline \multicolumn{5}{|l|}{ Diatoms } \\
\hline Actinoptychus senarius & 0.56 & - & - & - \\
\hline Amphiprora alata & - & 4.40 & 6.33 & - \\
\hline Amphora plicata & 0.11 & - & - & - \\
\hline Asterionella glacialis & - & - & 0.11 & - \\
\hline Asteromphalus hookeri & 28.30 & 0.22 & 36.79 & - \\
\hline Bacteriastrum delicatulum & 0.22 & 0.40 & - & 2.84 \\
\hline Bacteriastrum elongatum & 0.34 & - & 0.21 & - \\
\hline Bacteriastrum hyalinium & 0.11 & 1.10 & - & - \\
\hline Bacteriastrum furcatum & 3.48 & - & - & 0.20 \\
\hline Biddulphia longicuris & - & - & - & 0.39 \\
\hline Biddulphia mobiliensis & - & - & - & 7.84 \\
\hline Biddulphia sinensis & 0.11 & - & - & - \\
\hline Chaetoceros affinis & - & - & 1.07 & 0.59 \\
\hline Chaetoceros anastomosans & 1.24 & - & 0.97 & 5.69 \\
\hline Chaetoceros coarcticus & 0.56 & - & 0.32 & 5.69 \\
\hline Chaetoceros concavicornis & - & - & - & 0.51 \\
\hline Chaetoceros contortus & - & 2.20 & 1.18 & 26.38 \\
\hline Chaetoceros criophilus & - & 0.88 & - & - \\
\hline Chaetoceros danicus & 0.56 & - & - & 15.59 \\
\hline Chaetoceros decipiens & 8.20 & 8.59 & 2.47 & - \\
\hline Chaetoceros dichaeta & 3.93 & 11.01 & - & 0.78 \\
\hline Chaetoceros lorenzianus & - & 0.66 & - & - \\
\hline Chaetoceros socialis & - & - & 0.54 & 0.20 \\
\hline Chaetoceros sp. & 0.11 & - & - & - \\
\hline Coscinodiscus bouvet & 0.56 & 0.90 & 0.32 & - \\
\hline Coscinodiscus radiatus & - & - & - & 0.10 \\
\hline Cyclotella sp. & 0.11 & - & - & - \\
\hline Cylindrotheca closterium & 0.11 & - & 0.21 & 0.10 \\
\hline
\end{tabular}

Table 2 continued on pages 93-95. 
Table 2. Continued from pages 91-92.

\begin{tabular}{|c|c|c|c|c|}
\hline Taxon & $\begin{array}{c}\text { Inner } \\
\text { Harbour }\end{array}$ & $\begin{array}{c}\text { Ballast } \\
\text { water }\end{array}$ & Pamunugama & Panadura \\
\hline Ditylum brightwellii & - & 6.61 & 0.11 & - \\
\hline Entomoneis alata & 0.22 & - & 0.64 & 0.20 \\
\hline Eucampia antarctica & 1.12 & - & - & 0.10 \\
\hline Eucampia groenlandica & 2.36 & 0.66 & 2.57 & 0.29 \\
\hline Hemiaulus hauckii & - & 1.76 & 13.30 & 8.14 \\
\hline Hemiaulus membranaceus & - & - & 0.43 & - \\
\hline Hemiaulus sinensis & - & - & 0.64 & - \\
\hline Lauderia annulata & - & - & - & 0.78 \\
\hline Lauderia borealis & 0.50 & - & 0.58 & 0.63 \\
\hline Leptocylindrus danicus & - & 0.44 & - & - \\
\hline Leptocylindrus minimum & - & 2.20 & - & - \\
\hline Licmophora flabellate & 1.91 & - & - & - \\
\hline Melosira granulate & - & - & - & 0.20 \\
\hline Melosira nummuloides & - & - & - & 0.10 \\
\hline Nitzschia acicularis & - & 0.22 & - & - \\
\hline Nitzschia closterium & 0.67 & 2.20 & - & - \\
\hline Nitzschia longissima & 0.56 & - & 1.18 & 0.39 \\
\hline Nitzschia pungens & 0.56 & - & - & - \\
\hline Nitzschia sigma & 2.47 & - & - & - \\
\hline Odontella aurita & 1.91 & 1.32 & 0.54 & - \\
\hline Paralia sulcata & - & - & 0.43 & - \\
\hline Pleurosigma angulatum & 0.67 & - & 1.07 & - \\
\hline Proboscia alata & 0.45 & 0.44 & 0.11 & - \\
\hline Psuedonitzschia fraudulenta & 0.45 & - & - & - \\
\hline Rhizosolenia alata & 3.03 & - & - & - \\
\hline Rhizosolenia hyaline & - & - & - & 1.37 \\
\hline Rhizosolenia shrubsoki & 3.26 & 0.22 & 0.75 & - \\
\hline Rhizosolenia stolforthii & - & - & 7.19 & - \\
\hline Skeletonema costata & - & - & - & 0.20 \\
\hline Skeletonema costatum & 0.11 & - & 0.11 & 0.10 \\
\hline Stephanopyxis palmeriana & - & - & 0.86 & - \\
\hline Striatella unipunctata & 0.22 & - & 0.11 & 0.59 \\
\hline Thalassionema bacillare & - & - & 1.07 & 0.49 \\
\hline Thalassionema nitzschoides & 1.46 & 1.10 & - & - \\
\hline Thalassiosira decipiens & 0.90 & - & - & - \\
\hline Thalassiosira gravida & - & 0.44 & - & - \\
\hline Triceratium alternans & - & 0.88 & - & 0.49 \\
\hline
\end{tabular}

Table 2 continued on pages $94-95$ 
Table 2. Continued from pages 91-93.

Taxon $\begin{gathered}\text { Inner } \\ \text { Harbour }\end{gathered} \quad \begin{gathered}\text { Ballast } \\ \text { water }\end{gathered}$ Pamunugama Panadura

\section{Dinoflagellates}

Ceratium carriense

0.90

0.11

Ceratium extensum

0.45

Ceratium furca

0.54

2.06

Ceratium lineatum

Ceratium massiliense

$-$

1.76

-

$-$

6.85

0.88

Ceratium setaceum

Ceratium trichocercos

Ceratium tripos

Ceratocorys sp.

Dinophysis caudate

Dinophysis dentate

Dinophysis micropterygia

Fragilidium sp.

Gonyaulux verior

Gymnodinium verruculosum

Gyrodinium spirale

Gyrodinium uncatenum

3.30

$\begin{array}{ll}- & 2.20\end{array}$

- $\quad-$

- $\quad-$

- $\quad-$

- $\quad-$

- $\quad-$

- $\quad-$

$\begin{array}{ll}- & 4.40\end{array}$

4.40
0.88

$-$

Kofoidinium velleloides

$-$

Ornithocercus thurni

Oxyphysis oxytoxoides

Peridinium cerasus

Phalacroma pulchellum

Polykrikos sp.

Polarella glacialis

Protoperidinium depressum

Protoperidinium elegans

Protoperidinium leonis

Protoperidinium oceanicum

Protoperidinium sp

Pyrophacus horologicum

\section{Chlorophyceae algae}

Actinastrum hantzchii

Ophiocytium parvulum

0.22

0.88

Pediastrum duplex

0.22

0.66

0.20

0.56

9.77

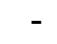

0.32

0.10

0.11

0.20

0.10

0.10

0.10

$-$

0.88

$-$

-

$-\quad-$

0.97

$-$

$-\quad-$

0.11

0.11

0.44

0.34

\section{Ciliates}

Actinsphaerium sp.

Didinium nasutum

Strombidium cornucopiae

$\begin{array}{cccc}0.22 & - & 1.82 & 0.20 \\ - & 2.20 & - & - \\ - & - & - & 0.98\end{array}$

0.10

$0.97 \quad 2.94$

2.79

0.32

0.29

0.39

-

0.11

0.20

-
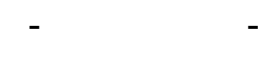

0.98

Table 2 continued on page 95 . 
Table 2. Continued from pages 91-94

\begin{tabular}{|c|c|c|c|c|}
\hline Taxon & $\begin{array}{c}\text { Inner } \\
\text { Harbour } \\
\end{array}$ & $\begin{array}{c}\text { Ballast } \\
\text { water }\end{array}$ & Pamunugama & Panadura \\
\hline \multicolumn{5}{|l|}{ Tintinnids } \\
\hline Dadyiella acuta & - & - & - & 0.10 \\
\hline Eutintinnis pectinis & 2.58 & 0.88 & - & - \\
\hline Helicostomella edentate & - & - & 0.11 & - \\
\hline Ormosella trachelium & - & 2.20 & - & - \\
\hline Rabdonella brandti & - & - & 0.11 & - \\
\hline \multicolumn{5}{|l|}{ Other } \\
\hline Brachyuran larva & - & - & - & 0.10 \\
\hline Cladoceran & - & - & - & 0.10 \\
\hline Brachionus calyciflorus & 0.11 & - & - & - \\
\hline Ephyra larva & - & - & 0.21 & - \\
\hline Fish larvae & 1.35 & - & - & 0.88 \\
\hline Grammatophora angulosa & - & - & - & 0.20 \\
\hline Ophiopluteus larva & - & - & - & 0.29 \\
\hline Paragloborotalia sp. & 0.11 & - & - & - \\
\hline Polychaete larvae & - & - & - & 0.10 \\
\hline Sagitta enflata & - & - & - & 0.10 \\
\hline Total number of taxa & 63 & 56 & 55 & 71 \\
\hline $\begin{array}{l}\text { Total number of } \\
\text { individuals }\end{array}$ & $222,62,50$ & $113,51,00$ & $233,10,00$ & $254,95,00$ \\
\hline
\end{tabular}

Of the 159 taxa of plankton recorded, ballast water contained 28 taxa that were not recorded elsewhere in the three local sampling sites. These taxa can be regarded as alien plankton and their percentage occurrence was $50 \%$ with respect to the total number of ballast water taxa and $17.6 \%$ with respect to the total number of taxa found (Table 3). Of the plankton recorded in this study, diatoms, dinoflagellates and chlorophyceae algae were photosynthetic forms. The total number of these photosynthetic taxa found in the ballast water was 32 with a percentage occurrence of $57.1 \%$ to the total number of ballast water taxa. The number of photosynthetic taxa found in the inner harbour, Pamunugama and Panadura were 48, 43 and 44 having percentage occurrence of $75 \%, 78.2 \%$ and $62 \%$ with respect to the number of taxa recorded at each site.

The percentage occurrence of site-specific taxa between the four sites were not significantly different from each other ( $p>0.05$; Chi-Square test) (Figure 2). However, plankton samples of the three local sites clustered together while those of the ballast water formed a separate cluster in the Bray-Curtis similarity matrix (Figure 3). This ballast water plankton community structure was significantly different from that of the local plankton community ( $<0.05$; one-way ANOSIM) confirming that ballast 
water plankton community was so unique where its species composition, species richness and abundance were not at all similar to those of the local plankton community.

Table 3. Distribution and the \% occurrence of plankton in the ballast water, inner harbour, Panadura and Pamunugama

\begin{tabular}{lcc}
\hline \multicolumn{1}{c}{ Taxon Category } & $\begin{array}{c}\text { Number of } \\
\text { Taxa }\end{array}$ & $\begin{array}{c}\text { Percentage occurrence } \\
\text { (total number of taxa = 159) }\end{array}$ \\
\hline $\begin{array}{l}\text { Number of taxa found in } \\
\text { ballast water } \\
\text { Number of taxa found only in } \\
\text { ballast water = Alien } \\
\text { introduced species }\end{array}$ & 28 & $35.2 \%$ \\
$\begin{array}{l}\text { Number of taxa found in inner } \\
\text { harbour, Panadura and } \\
\text { Pamunugama, but not in } \\
\text { ballast water }\end{array}$ & 103 & $17.6 \%$ \\
\hline
\end{tabular}

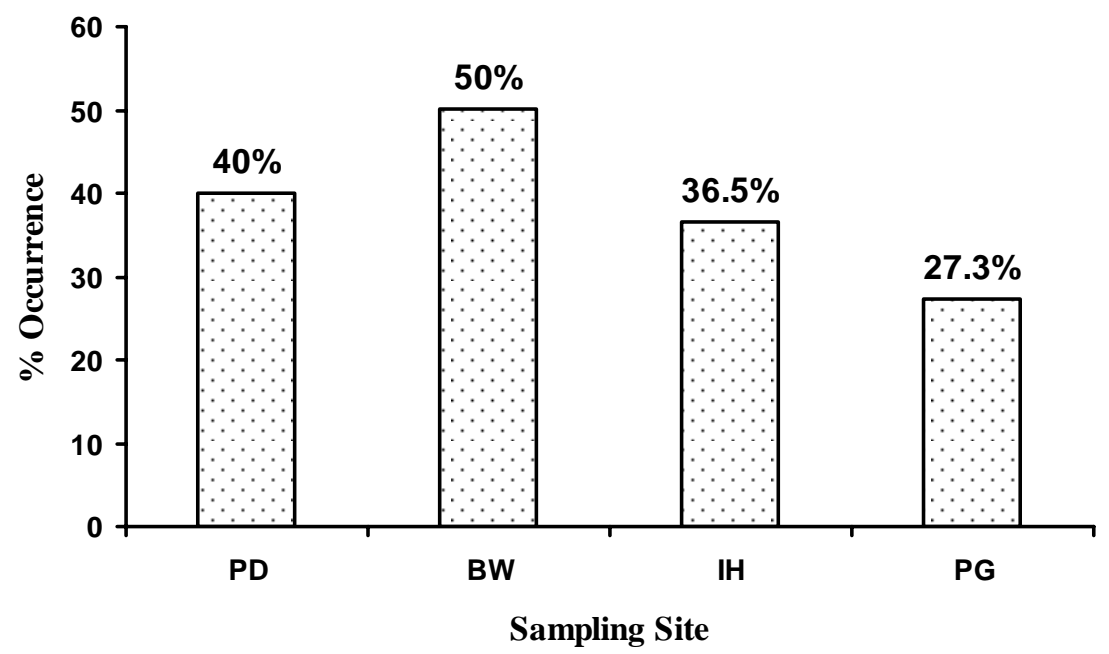

Figure 2. The percentage occurrence of site-specific palnkton between the four sampling sites (PD-Panadura, BW-Ballast water, IH-Inner Harbour, PGPamunugama).

The DO, salinity, temperature, conductivity and $\mathrm{pH}$ varied between the four sampling sites (Table 4). However, the variation of none of these physico-chemical parameters was significantly different between these sites ( $\mathrm{p}>0.05$; one-way ANOVA) (Table 5). This suggested that quality and condition of water between the four sampling sites were more or less similar to each other. 


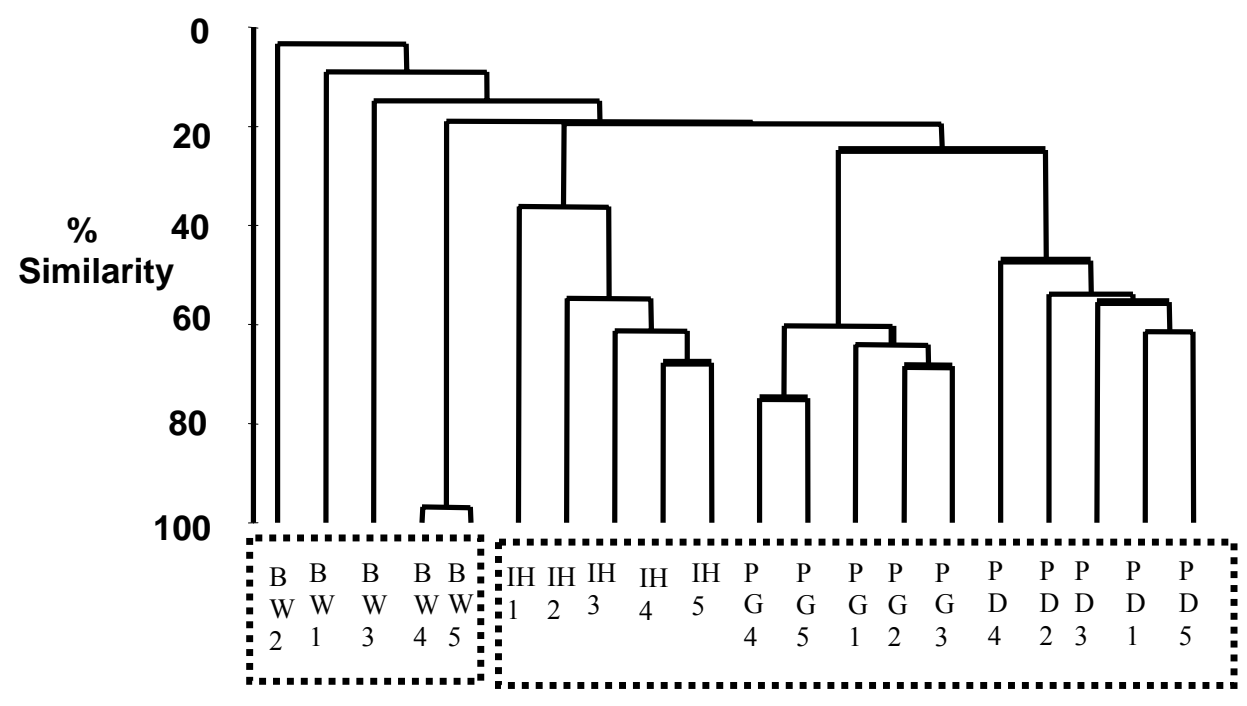

Figure 3. Dendrogram based on the Bray-Curtis similarity matrix showing the clustering of plankton communities between the ballast water and the three local sites (BW- Ballast water, IH- Inner Harbour, PG - Pamunugama and PD - Panadura). Plankton communities of the three local sites clustered separately from the ballast water at plankton community at $20 \%$ similarity level. The structure and composition of this ballast water community were significantly different from those of the local plankton community $(\mathrm{p}<0.05$; one-way ANOSIM).

Table 4. Variation of physico-chemical parameters of test water between the four sampling sites. Mean \pm SE values are presented $(n=3)$.

\begin{tabular}{lccccc}
\hline $\begin{array}{c}\text { Sampling } \\
\text { site }\end{array}$ & $\begin{array}{c}\mathrm{DO} \\
\left(\mathrm{mgL}^{-1}\right)\end{array}$ & $\begin{array}{c}\text { Salinity } \\
(\mathrm{ppt})\end{array}$ & $\begin{array}{c}\text { Temperature } \\
\left({ }^{0} \mathrm{C}\right)\end{array}$ & $\begin{array}{c}\text { Conductivity } \\
\times 1^{3} \\
\left(\mathrm{mmho}^{3}\right)\end{array}$ & $\mathrm{pH}$ \\
\hline Inner & $5.52 \pm 1.37$ & $33.6 \pm 1.40$ & $27.8 \pm 0.12$ & $49.0 \pm 1.8$ & $7.94 \pm 0.18$ \\
harbour & & & & & \\
Panadura & $7.50 \pm 0.11$ & $31.4 \pm 0.81$ & $31.9 \pm 0.29$ & $49.2 \pm 2.3$ & $8.2 \pm 0.06$ \\
Pamunugama & $8.08 \pm 0.11$ & $29.6 \pm 1.12$ & $31.2 \pm 0.50$ & $49.5 \pm 2.1$ & $8.15 \pm 0.07$ \\
Ballast water & $6.78 \pm 0.27$ & $32.8 \pm 3.26$ & $30.9 \pm 0.99$ & $56.2 \pm 4.0$ & $8.06 \pm 0.07$ \\
\hline
\end{tabular}

\section{Discussion}

The major objective of the present study was to investigate whether marine plankton are introduced into Sri Lankan coastal zone through ballast water of cargo ships arriving at there. From only the five ships sampled, an overwhelmingly large percentage as high as $50 \%$ of plankton were found in their ballast holds that are totally alien to the Sri Lankan coastal waters. 
Table 5. Summary of the One-way ANOVA $(\alpha=0.05)$ for physico-chemical parameters between the four sampling sites.

\begin{tabular}{lllllll}
\hline \multirow{2}{*}{ Parameter } & $\begin{array}{l}\text { Source } \\
\text { of } \\
\text { variance }\end{array}$ & \multicolumn{1}{c}{ DF } & \multicolumn{1}{c}{ SS } & MS & F & P \\
& Site & 3 & 18.26 & 6.09 & 2.45 & 0.101 \\
& Error & 16 & 39.80 & 2.49 & & \\
Salinity & Total & 19 & 58.06 & & & \\
& Site & 3 & 46.2 & 15.4 & 0.85 & 0.488 \\
& Error & 16 & 290.4 & 18.1 & & \\
Temperature & Total & 19 & 336.6 & & & \\
& Site & 3 & 48.75 & 16.25 & 9.61 & 0.191 \\
& Error & 16 & 27.06 & 1.69 & & \\
Conductivity & Total & 19 & 75.81 & & & \\
x 10 & Site & 2 & 15.6 & 7.8 & 1.79 & 0.209 \\
& Error & 12 & 52.5 & 4.4 & & \\
pH & Total & 14 & 68.1 & & & \\
& Site & 3 & 0.1972 & 0.0657 & 1.11 & 0.375 \\
& Error & 16 & 0.9484 & 0.0593 & & \\
\hline & Total & 19 & 1.1456 & & & \\
\hline
\end{tabular}

According to the Colombo harbour master's statistics records, the ships sampled in the present study have arrived at the Colombo harbour from neighboring sea ports such as port Klang, port Chittagong, port Penang, port Bombay and port Somalia. All these ports including the Colombo harbour occur within the Indian Oceanic region where the sea water mixes continually by north and south equatorial oceanic currents (Levinton 2008). As such the physico-chemical parameters such as DO, temperature, salinity, conductivity and $\mathrm{pH}$ between the ballast water holds and the three local sampling sites are more or less similar to each other so that it is not surprising to find no significant differences among these factors between the four study sites. This may also be the reason for species such as Eucalanus subcrassus and Eucampia groenlandica to thrive in all four sites.

Of the many plankton recoded in this study photosynthetic forms such as diatoms, dinoflagellates and chlorophyceae algae need sunlight for their food production, growth and survival. The light environment in the three local sampling sites is undoubtedly superior to that in the ballast tanks that are positioned in the dark bottom of the ships well below the outer sea water level. It is a fact that these taxa will have to survive in these dark tanks for 2 4 weeks or more during a voyage so that most of the plankton including photosynthetic forms succumb due to absence of sunlight. Previous studies 
(Carlton 1985; Williamson and Fitter 1996; Kolar and Lodge 2001) have shown that only a small proportion of approximately $10 \%$ of plankton will survive passage from the transportation stage to the introduction stage, with most organisms succumbing in transit due to drastic changes of physicochemical parameters such as sunlight. Even the survived organisms are expected to be weak (Kolar and Lodge, 2001) therefore they have less chance to successfully re-colonize in the new environment after being de-ballasted.

In addition, almost all organisms have autecological optima to thrive in a given environment which is governed by one or a combination of factors such as adequate water, nutrients, photoperiod, temperature, natural predators, pollutants, diseases and aggressive competitors etc. (Ricklefs 1990; Gaiser et al. 1998; Stevenson et al. 1999). This is particularly true for an introduced species as they will have to live in a new habitat where those environmental factors might be totally different to those in their original habitat so that only a small percentage of the introduced species become established in the new habitat concerned. Since the physico-chemical factors in the ports of origin and Colombo harbour are more or less the same, natural biotic phenomena such as predation or competition might also have affected ballast water community to change its composition after being discharged into the Colombo harbour. In spite of these facts, the number of planktonic taxa found in the ballast water was 58, but during the ballasting stage at the respective ports of origin the number of panktonic taxa that accidentally pumped into the ballast tanks would have been definitely much higher than this recorded number.

Although statistically not significant, a decrease of the site-specific taxa between inner harbour and Pamunugama site was noted (Figure 2). Further, there were 20 different taxa that are common to both inner harbour and Pamunugama. While the plankton found at Pamunugama are not certainly those contained in the cargo ships sampled in the present study, the north bound ocean currents around the Colombo harbour (Jayaweera 1999), may have carried the plankton that are released earlier and were later added to the native plankton assemblage at Pamunugama, thus reducing the sitespecificity whilst increasing the palnktonic heterogeneity there. Alternatively, they might be naturally diluted in the massive water mass of the ocean on their way to Pamunugama. However, it seems that this aspect needs further investigation.

Although the ships sampled for the present investigation are assigned for routine transportation between Sri Lanka and the respective countries in the Indian Ocean, many other ships arrive at Colombo from far away ports. It was noticed at Colombo harbour there were many cargo ships arrived from far away European, American and Australian ports and, ports in the far eastern countries such as Japan (Harbour masters record- Colombo harbour). It is possible that these ships woud contain completely different plankton assemblages as these countries are well out side the Indian Ocean facing a completely different environmental set up. However, these ships were not accessible for ballast water sampling due to security reasons so that receiving 
a comprehensive and reliable number of alien planktonic taxa was beyond reach. Most probably the validity of the present study could have been substantially improved with those plankton if there were any.

Even though 28 totally alien planktonic taxa were found in the five cargo ships sampled in the present study, the introduction potential of alien plankton into Sri Lankan coastal zone would be undoubtedly massive given the fact that the Colombo harbour receives approximately 5000 ships annually. Further, plankton were sampled using a plankton net in which the mesh size was $55 \mu \mathrm{m}$ hence nanoplankton could be easily escaped together with other microscopic unicellular organisms such as bacteria and life forms such as viruses. The ecological implications and health hazards of these nanoplankton, bacteria and viruses could not be easily undermined. For example, Anil et al. (2002) showed that ballast waters offer conducive situation for micro organisms such as bacteria, viruses and dinoflagellates to translocate into far away regions and cause deleterious effects to local flora and fauna through their toxigenic, proliferative and over-competitive characteristics. Even without data on many cargo ships, nanoplankton and bacteria etc, the present study clearly showed that a large number of alien plankton are introduced into the Sri Lankan coastal zone but the actual number of taxa that are accidentally introduced via ballast water might be much greater than the values reported in the present study. Further, studies on the impacts of alien species on the native biota are recommended so that the full effect of this accidental species introduction could be properly assessed. Results of the present study would certainly provide baseline information for those studies.

\section{Acknowledgements}

Financial assistance and other logistic support provided by the Marine Pollution Prevention Authority of Sri Lanka are gratefully acknowledged. The Sri Lanka Ports Authority and the Sri Lanka Navy permitted to do the field sampling and permitted access to log data. Prof. U. S. Amarasinghe, Department of Zoology, University of Kelaniya and an anonymous reviewer provided valuable suggestions to improve the quality of the manuscript. We gratefully acknowledge their assistance.

\section{References}

Anil, A.C., K. Venkat, S. S. Sawant, M. Dileepkumar, V. K. Dhargalkar, N. Ramaiah, S. N. Harkantra \& Z. A. Ansari 2002.

Marine bioinvasion: Concern for ecology and shipping. Current Science 83(3): 214-218.

Arvin, P.L. 1977.

Introduction to the common Marine Zooplankton of Peninsular Malaysia 108p.

Benson, H. J. 2002. 
Microbiological Applications, Laboratory Manual in General Microbiology. McGraw-Hill, the McGraw Hill Companies, Inc., New York, 478p.

Boney, A.D. 1979.

Studies in Biology, No. 52: Phytoplankton, Edward Arnold Ltd, London. 116p.

Clarke, K. R. \& R. M. Warwick 2001.

Changes in Marine Communities: An Approach to Statistical Analysis and Interpretation, $2^{\text {nd }}$ Edition, PRIMER-E: Plymouth.

Carlton, J. T. 1985.

Transoceanic and interoceanic dispersal of coastal marine organisms: The biology of ballast water. Oceanography and Marine Biology Annual Review 23:313-371.

Carlton, J. T. 1987.

Patterns of transoceanic marine biological invasions in the Pacific Ocean. Bulletin of Marine Sciences 41(2): 452-465.

Carlton, J. T. \& J. B. Geller 1995.

Ecological Roulette: The global transport of non-indigenous marine organisms. Science 261(6):78-82.

Gaiser, E. E., T. E. Philippi \& B. E. Taylor 1998.

Distribution of diatoms among intermittent ponds on the Atlantic coastal plain: development of a model to predict drought periodicity from surface-sediment assemblages. Journal of Paleolimnology 20: 71-90.

Gollasch, S. 1997.

Removal of barriers to the effective implementation of ballast water control and management measures in developing countries. GEF/IMO/UNDP Project.188p.

Guglielmo, L \& A. Ianora 1995.

Atlas of Marine Zooplanktons (Copepods), Straits of Magellan, Springe-Verlag, Berlin, Heidelberg, New York. 279p.

Hallegraeff, G. M. \& C. J. Bolch 1991.

Transport of toxic dinoflagellate cysts via ship's ballast Water.

Marine Pollution Bulletin 22(1):27-30.

Jayaweera, M. 1999.

Environment improvement study, Port of Colombo, Sri Lanka (Main

Text). Sri Lanka Ports Authority, Sri Lanka.187p.

Kolar, C.S. \& D.M. Lodge 2001.

Progress in invasion biology: predicting invaders. Trends in Ecology and Evolution 16:199-204.

Levinton, J.S. 2008.

Marine Biology; Function, Biodiversity, Ecology. Oxford University Press. Third Edition, p 30-60.

Locke, A., D. M Reid, van Leeuwen, H. C. Sprules, W. G. \& J.T. Carlton 1993. 
Ballast water exchange as a means of controlling dispersal of freshwater organisms by ships. Canadian Journal of Fisheries and Aquatic Sciences 50:2086-2093.

Lodge, D. M. 1993.

Biological invasions: Lessons for ecology. Trends in Ecology and Evolution 8(4):133-137.

Medcof, J. C. 1975.

Living marine animals in a ships' ballast water. Proceedings of the Netherlands Shellfish Assessment 65:54-55.

Newell, G.E. \& R.C. Newell 1973.

Marine Plankton, Practical Guide. Hutchinson Educational, London, $244 p$.

Ostenfeld, C. H. 1908.

On the immigration of Biddulphia sinensis Grev. and its occurrence in the North Sea during 1903-1907. Medd. Komm. Havunders., Ser. Plankton 1(6):1-46.

Ricklefs, R. E. 1990.

Ecology. $3^{\text {rd }}$ Edition. W.H. Freeman and Company. New York, 508p. Reeve, M. R. 1993.

The impact of gelatinous zooplankton predators on coastal and shelf ecosystems. BOC Theme Session Dublin, September 1993. ICES Dublin, 1993:1-11.

Roberts, L. 1990.

Zebra mussel invasion threatens U.S. waters. Science 249 (21):13701372.

Shushkina, E. A. \& E. I. Musayeva 1990.

Structure of planktic community of the Black Sea epipelagic zone and its variation caused by invasion of a new ctenophore species. Oceanology 30(2):225-228.

Stevenson, R. J., P. R. Sweets, Y. Pan, \& R. E. Schultz. 1999.

Algal community patterns in wetlands and their use as indicators of ecological conditions. In: Proceedings of INTECOL's $\mathrm{V}^{\text {th }}$ International Wetland Conference (A. J. McComb \& J. A. Davis eds), pp.517-527, Gleneagles Press. New York,

Stewart, J. E. 1991.

Introductions as factors in diseases of fish and aquatic invertebrates.

Canadian Journal of Fisheries and Aquatic Sciences 48(1):110-117.

Subba Rao, D. V., W. G Sprules, A. Locke \& J.T. Carlton. 1994.

Exotic phytoplankton from ships' ballast waters: Risk of potential spread to mariculture sites on Canada's east coast. Aquatic Sciences 937:1-51.

Suwanrumpha, W. 1987.

A key for the identification of copepods collected in the Gulf of Thailand waters. Technical paper No. 29/4. Marine Fisheries Laboratory, Marine Fisheries Division. Department of Fisheries, Thailand,188p. 
Vinogradov, M. Ye, E. A Shushkina, E. I. Musayeva, \& P.Yu. Sorokin. 1989.

A newly acclimated species in the Black Sea: The ctenophore Mnemiopsis leidyi (Ctenophora: Lobata). Oceanology 29(2):220-224. Wickstead, J.H. 1965.

An Introduction to the Study of Tropical Plankton, Hutchinson, London, $154 \mathrm{p}$.

Williamson, M. \& A. Fitter. 1996.

The characteristics of successful invaders. Biological Conservation $78: 163-170$. 